\title{
HUBUNGAN ANTARA PENGGUNAAN MEKANISME KOPING YANG BERFOKUS PADA MASALAH DENGAN KENAKALAN PADA REMAJA
}

\author{
Ayu Dekawaty \\ Program Studi Ilmu Keperawatan STIKes Muhammadiyah Palembang \\ Email : nyimasayudekawaty@gmail.com
}

\begin{abstract}
ABSTRAK
Latar Belakang: Remaja merupakan masa transisi dari masa anak-anak menjadi dewasa, terjadi perubahan-perubahan mulai dari perubahan fisik, proses berfikir, emosi, dan perasaan mampu untuk menjadi dewasa. Remaja adalah individu yang berusia 11-21 tahun dan belum menikah. Pada masa transisi tersebut kemungkinan dapat menimbulkan masa krisis, yang ditandai dengan kecenderungan munculnya perilaku menyimpang. Kemampuan remaja untuk memecahkan masalahnya secara adekuat berpengaruh terhadap bagaimana ia mudah mencari pemecahan masalah. Metode Penelitian: Penelitian ini merupakan penelitian analitik dengan desain cross sectional dan teknik purposive sampling pada siswa Panti Sosial X. Jumlah responden yang diambil dalam penelitian ini adalah 80 responden. Variabel independen adalah mekanisme koping yang berfokus pada masalah (causioness, instrumental action, dan negotiation) dan variabel dependen kenakalan pada remaja di Panti Sosial Marsudi Putra Dharmapala Indralaya (kenakalan biasa/ringan, kenakalan sedang, serta kenakalan khusus/ berat). Alat pengumpul data yang digunakan dalam penelitian ini adalah kuesioner. Penelitian ini menggunakan uji Chi-square $\left(\mathrm{X}^{2}\right)$ dengan tingkat kesalahan $5 \%$ atau 0,05. Hasil penelitian: menunjukkan adanya hubungan yang bermakna antara penggunaan mekanisme koping yang berfokus pada masalah dengan kenakalan pada remaja ( $\rho$ value 0,000$)$. Secara spesifik didapatkan hasil $\rho$ value 0,002 untuk 'instrumental action' serta $\rho$ value 0,005 untuk 'negotiation', yang menunjukkan ada hubungan yang bermakna antara kedua variabel tersebut. Sedangkan 'causioness' memiliki $\rho$ value 0,0819 yang artinya tidak terdapat hubungan antara kedua variabel tersebut. Diskusi: siswa diharapkan dapat menggunakan mekanisme koping yang adaptif sehingga dapat menyelesaikan setiap permasalahan dengan baik.
\end{abstract}

\section{Kata kunci : Mekanisme Koping dan Kenakalan Remaja}

\section{ABSTRACT}

Introduction: Adolescent is a transition period from child to adult, there are many changes from physical, thought process, and feeling can be an adult. Adolescent is a person of 11-21 years old and not yet marriage. In the transition period may be can lead a crisis period, that will be a juvenile delinquency. The adolescentia's potency to solve a problem adequately influences how easily he looks for problem solving. Method: The method of this research is analytic with cross sectional design and purposive sampling technique to student at Social Building X. The responden of this research is 80 people. The independent variable is problem focused coping mechanism (causionee, instrumental action, and negotiation) and the dependent variable is juvenile delinquency (general delinquency, moderate delinquency, and heavy delinquency). Data is collected by questioner. This research use chi-square test with significant level 5\% (0,05). Result: This research result show there is a significant correlation of problem focused coping mechanism's utilization and juvenile ( $\rho$ value 0,000). Spesificaly, $\rho$ value 0,002 for instrumental action and $\rho$ value 0,005 for negotiation, that 
show there is correlation of that variable. Even though causioness have $\rho$ value 0,0819, that means there is not significant correlation of that variable. Discussion: we have to expect for student to use adaptively's coping mechanism so can solve many problems well.

\section{Keyword : Problem focused Coping Mechanism and Juvenile Delinquency}

\section{PENDAHULUAN}

Di era globalisasi yang penuh dengan perubahan nilai-nilai moral seperti saat ini, sikap dan tingkah laku manusia juga banyak yang ikut berubah. Dalam situasi demikian orang-orang cenderung memakai cara sendiri dalam usaha mencapai tujuan yang diinginkan sehingga timbullah banyak penyimpangan tingkah laku dan perbuatan kriminal, khususnya yang dilakukan oleh remaja dan orang-orang muda (Kartono, 2003).

Remaja merupakan masa transisi dari masa anak-anak menjadi dewasa, terjadi perubahan-perubahan mulai dari perubahan fisik, proses berfikir, emosi, dan perasaan mampu untuk menjadi dewasa. Remaja adalah individu yang berusia 11-24 tahun dan belum menikah (Sarwono, 2005). Pada masa transisi tersebut kemungkinan dapat menimbulkan masa krisis, yang ditandai dengan kecenderungan munculnya perilaku menyimpang. Pada kondisi tertentu perilaku menyimpang tersebut akan menjadi perilaku yang mengganggu (Ekowarni, 1993).
Banyak remaja yang akhirnya menyelesaikan masalah tidak sesuai dengan harapan mereka, hal tersebut disebabkan karena ketidakmampuan mereka untuk mengatasi masalahnya menurut cara yang mereka yakini. Seperti dijelaskan oleh Anna dalam Hurlock (1980), "Banyak kegagalan yang seringkali disertai akibat yang tragis, bukan karena ketidakmampuan individu tetapi karena kenyataan bahwa tuntutan yang diajukan kepadanya justru pada saat semua tenaganya telah dihabiskan untuk mencoba mengatasi masalah pokok yang disebabkan oleh pertumbuhan dan perkembangan seksual yang normal".

Remaja yang sehat mampu membetulkan kekeliruan sendiri dengan jalan; berfikir logis dan mampu membedakan harapan dan kenyataan. Mereka memiliki reality-testing yang sehat. Sebaliknya, remaja yang terganggu jiwanya (kenakalan remaja) akan memperalat fikirannya sendiri untuk membela dan membenarkan gambarangambaran semu dan tanggapan yang salah. Akibatnya, reaksi dan tingkah laku remaja menjadi salah kaprah; bisa menjadi 
liar dan tidak terkendali, selalu mencapai cara-cara yang keras serta perkelahian dalam menanggapi segala kejadian sehingga dapat menimbulkan kenakalan pada remaja (Kartono, 2003).

Menurut penelitian Mays (1963) di Inggris kejahatan remaja dari tahun 1938 hingga tahun 1962 bertambah 200\%; kejahatan seks bertambah 300\%, kekerasan dan kejahatan bertambah $2200 \%$ (Kartono, 2003). Tidak jauh berbeda dengan di Inggris, hampir setiap hari kasus kenakalan remaja juga kita temukan di media massa Indonesia, khususnya di kota-kota besar seperti Jakarta, Surabaya, dan Medan. Salah satu wujud dari kenakan remaja itu adalah penggunaan Narkotika, psikotropika, dan zat aditif lainnya (NAPZA). Wahyuni dalam Damandiri (2004) menjelaskan bahwa dari 15.000 kasus penggunaan NAPZA selama 2 tahun terakhir, $46 \%$ diantaranya dilakukan oleh remaja. Sebuah survei yang dilakukan oleh Badan koordinasi keluarga berencana nasional $(\mathrm{BKKBN})$ di 33 provinsi pada pertengahan tahun 2008 melaporkan bahwa 63 persen remaja di Indonesia usia sekolah SMP dan SMA sudah melakukan hubungan seksual di luar nikah dan 21 persen di antaranya melakukan aborsi. Persentasi remaja yang melakukan hubungan seksual pranikah tersebut mengalami peningkatan jika dibandingkan dengan tahun-tahun sebelumnya. Secara umum survei tersebut mengindikasikan bahwa pergaulan remaja di Indonesia makin mengkhawatirkan.

Menurut Sarwono (2005) kenakalan remaja adalah perilaku yang menyimpang dari atau melanggar hukum. Pada umumnya semua perilaku tersebut merupakan mekanisme kompensatoris untuk mendapatkan pengakuan terhadap egonya, disamping dipakai sebagai kompensasi pembalasan terhadap perasaan minder yang ingin 'ditebusnya' dengan tingkah laku 'sok', 'ngejago', hebat-hebat, aneh-aneh, dan kriminal. Lewat semua perbuatan tersebut mereka ingin tampak menonjol dan dikenal oleh banyak orang. Kartono (2003) juga menjelaskan bahwa kenakalan remaja merupakan cara adaptasi yang salah terhadap tuntutan zaman modern yang serba kompleks sekarang ini, semua polapola kebiasaan dan tingkah laku patologis, sebagai akibat dari pemasakan konflikkonflik batin sendiri secara salah, yang menimbulkan mekanisme reaktif/respon yang keliru atau tidak cocok (menggunakan escape mechanism dan defence mechanism).

Banyak faktor yang mempengaruhi timbulnya kenakalan remaja, diantaranya yaitu keluarga. Keluarga merupakan 
lingkungan sosial pertama yang memberikan pengaruh sangat besar bagi tumbuh kembang remaja. Secara ideal perkembangan remaja akan optimal apabila mereka bersama keluarganya harmonis, sehingga berbagai kebutuhan yang diperlukan terpenuhi. Dalam kaitannya dengan permasalahan remaja, keluarga akan merasa tidak mampu untuk mengatasi setiap tingkah laku menyimpang yang telah dilakukan sehingga mereka membutuhkan alternatif pilihan yang dapat digunakan untuk memperbaiki tingkah laku remaja tersebut, diantaranya dengan memasukkan anak-anak mereka ke panti rehabilitasi (Mighwar, 2006).

Secara umum, dalam menyelesaikan masalahnya remaja dapat menggunakan 2 jenis mekanisme koping, yaitu koping adapatif apabila remaja berbicara dengan orang lain, memecahkan masalah secara efektif, melakukan teknik relaksasi, latihan seimbang dan aktivitas konstruktif, serta koping maladaptif jika remaja makan berlebihan/tidak makan, bekerja berlebihan, dan menghindar (Stuart dan Sundeen, 1995).

Dalam masalah penyalahgunaan NAPZA (salah satu contoh jenis kenakalan berat/khusus) biasanya mereka memiliki mekanisme koping maladaptif yang ditandai dengan ketidakmampuan melakukan aktivitas secara wajar, mudah cemas, pasif, agresif dan cenderung depresi. Kemampuan remaja untuk memecahkan masalahnya secara adekuat berpengaruh terhadap bagaimana ia mudah mencari pemecahan masalah dengan melarikan diri. Hal ini juga berkaitan dengan mudahnya ia menyalahkan lingkungan dan lebih melihat faktor-faktor di luar dirinya yang menentukan segala sesuatu. Dalam hal ini, kepribadian yang tidak mandiri memainkan peranan penting dalam memandang perilaku menyimpang/kenakalan remaja sebagai satu-satunya pemecahan masalah yang dihadapi (Klasik, 2008).

\section{BAHAN DAN METODE}

Penelitian ini merupakan penelitian analitik dengan desain cross sectional. Pada penelitian ini, pengukuran koping yang berfokus pada masalah (problem focused coping) yang terdiri dari causionees, instrumental action, dan negotiation (variabel independen) dengan kenakalan remaja yang terdiri dari: kenakalan biasa, kenakalan sedang (menjurus kepada pelanggaran dan kejahatan), serta kenakalan berat/khusus (variabel dependen) dilakukan pada waktu yang sama dan 
tiap subjek penelitian hanya

dan menggunakan teknik purposive diobservasi satu kali. Pengambilan sampling dengan kriteria yang telah sampel dilakukan dengan total ditentukan peneliti sebelumnya. sampling, yaitu berjumlah 80 orang

HASIL

\section{A. Analisis Univariat}

1. Variabel Independen (Mekanisme Koping)

a. Mekanisme Koping 'Causioness'

Tabel 5.1

Distribusi Frekuensi Responden Berdasarkan Mekanisme Koping 'Causioness'

\begin{tabular}{|c|c|c|c|}
\hline \multirow[b]{2}{*}{ No. } & \multirow{2}{*}{$\begin{array}{l}\text { Mekanisme } \\
\text { Koping } \\
\text { Causioness }\end{array}$} & \multicolumn{2}{|c|}{ Jumlah } \\
\hline & & $\begin{array}{c}\text { Frekuensi } \\
\text { (n) }\end{array}$ & $\begin{array}{c}\text { Persentase } \\
(\%)\end{array}$ \\
\hline 1. & $\begin{array}{c}\text { Tidak } \\
\text { menggunakan }\end{array}$ & 46 & 57,5 \\
\hline 2. & Menggunakan & 34 & 42,5 \\
\hline & Total & 80 & 100,0 \\
\hline
\end{tabular}

Tabel 5.1 menunjukkan bahwa sebanyak 46 orang $(57,5 \%)$ dari 80 orang responden yang tidak menggunakan mekanisme koping 'causioness'.

b. Mekanisme Koping 'Instrumental Action'

Tabel 5.2

Distribusi Frekuensi Responden Berdasarkan Mekanisme Koping 'Instrumental

\begin{tabular}{|c|c|c|c|}
\hline \multirow[b]{3}{*}{ No. } & \multirow{3}{*}{$\begin{array}{l}\text { Mekanisme } \\
\text { Koping } \\
\text { Instrumental } \\
\text { Action }\end{array}$} & Action' & \\
\hline & & \multicolumn{2}{|c|}{ Jumlah } \\
\hline & & $\begin{array}{c}\text { Frekuensi } \\
\text { (n) }\end{array}$ & $\begin{array}{c}\text { Persentase } \\
(\%)\end{array}$ \\
\hline 1. & $\begin{array}{c}\text { Tidak } \\
\text { menggunakan }\end{array}$ & 67 & 83,8 \\
\hline 2. & Menggunakan & 13 & 16,3 \\
\hline & Total & 80 & 100,0 \\
\hline
\end{tabular}

Tabel 5.2 menunjukkan bahwa sebanyak 67 orang $(83,8 \%)$ dari 80 orang responden yang tidak menggunakan mekanisme koping 'instrumental action'. 
c. Mekanisme Koping 'Negotiation'

Tabel 5.3

Distribusi Frekuensi Responden Berdasarkan Mekanisme Koping 'Negotiation'

\begin{tabular}{|c|c|c|c|}
\hline \multirow{2}{*}{ No } & \multirow{2}{*}{$\begin{array}{c}\text { Mekanisme Koping } \\
\text { Negotiation }\end{array}$} & \multicolumn{2}{|c|}{ Jumlah } \\
\cline { 3 - 4 } & & Frekuensi (n) & Persentase (\%) \\
\hline 1. & Tidak menggunakan & 50 & 62,5 \\
\hline 2. & Menggunakan & 30 & 37,5 \\
\hline & Total & $\mathbf{8 0}$ & $\mathbf{1 0 0 , 0}$ \\
\hline
\end{tabular}

Tabel 5.3 menunjukkan bahwa sebanyak 50 orang $(62,5 \%)$ dari 80 orang responden yang tidak menggunakan mekanisme koping 'negotiation'

\section{Variabel Dependen (Jenis Kenakalan)}

Tabel 5.4

Distribusi Frekuensi Responden Berdasarkan Jenis Kenakalan

\begin{tabular}{|c|c|c|c|}
\hline \multirow{2}{*}{$\begin{array}{c}\text { No } \\
\cdot\end{array}$} & Jenis & \multicolumn{2}{|c|}{ Jumlah } \\
\cline { 3 - 4 } & Kenakalan & $\begin{array}{c}\text { Frekuen } \\
\text { si (n) }\end{array}$ & $\begin{array}{c}\text { Persentas } \\
\text { e (\%) }\end{array}$ \\
\hline 1. & Ringan & 23 & 28,8 \\
\hline 2. & Sedang & 13 & 16,3 \\
\hline 3. & Berat & 44 & 55,0 \\
\hline & Total & $\mathbf{8 0}$ & $\mathbf{1 0 0 , 0}$ \\
\hline
\end{tabular}

Tabel 5.4 menunjukkan bahwa responden dengan jenis kenakalan ringan sebanyak 23 orang $(28,8 \%)$, jenis kenakalan sedang sebanyak 13 orang $(16,3 \%)$, dan terbanyak dengan jenis kenakalan berat yaitu sebanyak 44 orang (55\%) dari 80 orang responden.

\section{B. Analisa Bivariat}

Analisa bivariat dimaksudkan untuk menggambarkan hubungan antara variabel independen dengan variabel dependen. Hasil analisa statistik disajikan dalam bentuk tabel sebagai berikut: 
1. Hubungan Antara Mekanisme Koping yang Berfokus pada Masalah dengan Kenakalan pada Remaja

Tabel 5.5

Hubungan Antara Mekanisme Koping yang Berfokus pada Masalah dengan Kenakalan pada Remaja

\begin{tabular}{|c|l|c|c|c|c|c|}
\hline \multirow{2}{*}{ No } & \multirow{2}{*}{ Mekanisme Koping } & \multicolumn{3}{|c|}{ Jenis Kenakalan } & \multirow{2}{*}{ Total } & \multirow{2}{*}{$\begin{array}{c}\boldsymbol{\rho} \\
\text { value }\end{array}$} \\
\cline { 3 - 5 } & & Ringan & Sedang & Berat & & \\
\hline 1. & Causioness & 12 & 4 & 19 & 35 & \\
\cline { 3 - 6 } & & $15,0 \%$ & $5,0 \%$ & $23,8 \%$ & $43,8 \%$ & \\
\hline 3. & Instrumental action & 0 & 0 & 19 & 19 & \\
& & $0 \%$ & $0 \%$ & $23,8 \%$ & $23,8 \%$ & \multirow{2}{*}{ Negotiation } \\
\cline { 3 - 6 } & & 11 & 9 & 6 & 26 & \\
& \multirow{2}{*}{ Total } & $13,8 \%$ & $11,3 \%$ & $7,5 \%$ & $32,5 \%$ & \\
& & 23 & 13 & 44 & 80 & \\
& & $28,8 \%$ & $16,3 \%$ & $55,0 \%$ & $100 \%$ & \\
\hline
\end{tabular}

Berdasarkan uji statistik Chi Square, penggunaan mekanisme koping yang didapatkan nilai $\rho$ value $0,000(<0,05)$. berfokus pada masalah dengan kenakalan Jadi dapat disimpulkan bahwa ada pada remaja. hubungan yang bermakna anatara

2. Hubungan Antara Mekanisme Koping yang Berfokus pada Masalah 'Causioness' dengan Kenakalan pada Remaja

Tabel 5.6

Hubungan Antara Mekanisme Koping yang Berfokus pada Masalah 'Causioness' dengan Kenakalan pada Remaja

\begin{tabular}{|c|c|c|c|c|c|c|}
\hline \multirow{2}{*}{ No. } & \multirow{2}{*}{$\begin{array}{c}\text { Mekanisme koping } \\
\text { 'Causioness' }\end{array}$} & \multicolumn{2}{|c|}{ Jenis Kenakalan } & \multirow{2}{*}{ Total } & \multirow{2}{*}{$\begin{array}{c}\text { p } \\
\text { value }\end{array}$} \\
\cline { 3 - 5 } & Ringan & Sedang & Berat & & \\
\hline \multirow{2}{*}{1.} & Tidak menggunakan & 12 & 8 & 26 & 46 & \\
\cline { 1 - 5 } 2. & Menggunakan & $15,0 \%$ & $10,0 \%$ & $32,5 \%$ & $57,5 \%$ & \\
& & $13,8 \%$ & $6,3 \%$ & $22,5 \%$ & $42,5 \%$ & \multirow{2}{*}{0,0819} \\
& Total & 23 & 13 & 44 & 80 & \\
& & $28,8 \%$ & $16,3 \%$ & $55,0 \%$ & $100 \%$ & \\
\hline
\end{tabular}

Berdasarkan tabel 5.6 didapatkan bahwa responden yang paling banyak menggunakan mekanisme koping yang berfokus pada masalah 'causioness' adalah responden dengan jenis kenakalan berat, yaitu sebanyak 18 orang $(22.5 \%)$ dari 80 orang responden.

Nilai $\rho$ value yang didapatkan dari uji statistik Chi Square adalah 0,0819 $(>0,05)$. Jadi dapat disimpulkan bahwa 
tidak ada hubungan yang bermakna antara penggunaan mekanisme koping 'causioness' dengan kenakalan pada remaja.

3. Hubungan Antara Mekanisme Koping yang Berfokus pada Masalah 'Instrumental action' dengan Kenakalan pada Remaja

Tabel 5.7

Hubungan Antara Mekanisme Koping yang Berfokus pada Masalah 'Instrumental action' dengan Kenakalan pada Remaja

\begin{tabular}{|c|c|c|c|c|c|c|}
\hline \multirow{2}{*}{ No } & \multirow{2}{*}{$\begin{array}{c}\text { Mekanisme koping } \\
\text { 'Instrumental action' }\end{array}$} & \multicolumn{3}{|c|}{ Jenis Kenakalan } & \multirow{2}{*}{ Total } & $\begin{array}{c}\boldsymbol{\rho} \\
\text { value }\end{array}$ \\
\cline { 3 - 6 } & Ringan & Sedang & Berat & & \\
\hline \multirow{2}{*}{1.} & Tidak menggunakan & 23 & 13 & 31 & 67 & \\
\cline { 1 - 6 } 2. & Menggunakan & 0 & 0 & 13 & 13 & \multirow{2}{*}{0,002} \\
\cline { 1 - 5 } & Total & $0 \%$ & $0 \%$ & $16,3 \%$ & $16,3 \%$ & \\
& & $28,8 \%$ & 13 & 44 & 80 & \\
& & $28,8 \%$ & $55,0 \%$ & $100 \%$ & \\
\hline
\end{tabular}

Berdasarkan tabel 5.7 didapatkan bahwa responden yang paling banyak menggunakan mekanisme koping yang berfokus pada masalah instrumental action' adalah responden dengan jenis kenakalan berat, yaitu sebanyak 13 orang $(16,3 \%)$ dari 80 orang responden, sedangkan jenis kenakalan ringan dan sedang tidak ada yang menggunakan mekanisme koping 'instrumental action'. Nilai $\rho$ value yang didapatkan dari uji statistik Chi Square adalah 0,002 (<0,05). Jadi dapat disimpulkan bahwa ada hubungan yang bermakna antara penggunaan mekanisme koping 'instrumental action' dengan kenakalan pada remaja.

1. Hubungan Antara Mekanisme Koping yang Berfokus pada Masalah 'Negotiation' dengan Kenakalan pada Remaja

Tabel 5.8

Hubungan Antara Mekanisme Koping yang Berfokus pada Masalah 'Negotiation' dengan Kenakalan pada Remaja

\begin{tabular}{|c|c|c|c|c|c|c|}
\hline \multirow{2}{*}{ No. } & \multirow{2}{*}{$\begin{array}{l}\text { Mekanisme koping } \\
\text { 'Negotiation' }\end{array}$} & \multicolumn{3}{|c|}{ Jenis Kenakalan } & \multirow{2}{*}{ Total } & \multirow{2}{*}{$\begin{array}{c}\rho \\
\text { value }\end{array}$} \\
\hline & & Ringan & Sedang & Berat & & \\
\hline 1. & Tidak menggunakan & $\begin{array}{c}12 \\
15,0 \%\end{array}$ & $\begin{array}{c}4 \\
5,0 \%\end{array}$ & $\begin{array}{c}34 \\
42,5 \%\end{array}$ & $\begin{array}{c}50 \\
62,5 \%\end{array}$ & \multirow{3}{*}{0,005} \\
\hline 2. & Menggunakan & $\begin{array}{c}11 \\
13,8 \%\end{array}$ & $\begin{array}{c}9 \\
11,3 \%\end{array}$ & $\begin{array}{c}10 \\
12,5 \%\end{array}$ & $\begin{array}{c}30 \\
37,5 \%\end{array}$ & \\
\hline & Total & $\begin{array}{c}23 \\
28,8 \%\end{array}$ & $\begin{array}{c}13 \\
16,3 \%\end{array}$ & $\begin{array}{c}44 \\
55,0 \%\end{array}$ & $\begin{array}{c}80 \\
100 \%\end{array}$ & \\
\hline
\end{tabular}


Berdasarkan tabel 5.8 didapatkan bahwa responden yang paling banyak menggunakan mekanisme koping yang berfokus pada masalah 'negotiation', adalah responden dengan jenis kenakalan ringan, yaitu sebanyak 11 orang $(13,8 \%)$ dari 80 orang responden.

Nilai $\rho$ value yang didapatkan dari uji statistik Chi Square adalah 0,005 $(<0,05)$. Jadi dapat disimpulkan bahwa ada hubungan yang bermakna antara penggunaan mekanisme koping 'instrumental action' dengan kenakalan pada remaja.

\section{PEMBAHASAN}

Berdasarkan hasil penelitian, didapatkan data bahwa remaja dengan tingkat kenakalan ringan biasanya menggunakan mekanisme koping 'causioness' dan 'negotiation', sedangkan pada responden yang diteliti tidak ada satu orang pun remaja dengan jenis kenakalan ringan menggunakan mekanisme koping 'instrumental action'. Remaja dengan jenis kenakalan sedang lebih banyak menggunakan mekanisme koping 'negotiation' dan 'causioness', sedangkan mekanisme koping 'instrumental action' tidak ada yang menggunakan. Berbeda dengan remaja yang mengalami jenis kenakalan ringan dan sedang, remaja dengan jenis kenakalan berat umumnya menggunakan mekanisme koping 'causioness' dan 'instrumental action' dan hanya sedikit sekali yang menggunakan mekanisme koping 'negotiation'. Hasil uji hubungan antara mekanisme koping yang berfokus pada masalah dengan kenakalan pada remaja didapatkan hasil $\rho$ value 0,000 $\quad(\rho<0,05) . \quad$ Hasil penelitian menunjukkan bahwa ada hubungan yang bermakna antara mekanisme koping yang berfokus pada masalah dengan kenakalan pada remaja.

Setiap periode mempunyai masalahnya sendiri-sendiri, namun masalah masa remaja sering menjadi masalah yang sulit diatasi baik oleh anak laki-laki maupun anak perempuan. Terdapat dua alasan bagi kesulitan itu. Pertama, sepanjang masa kanak-kanak , masalah anak-anak sebagian diselesaikan 
oleh orang tua dan guru-guru, sehingga kebanyakan remaja tidak berpengalaman dalam mengatasi masalah. Kedua, karena para remaja merasa diri mandiri, sehingga mereka ingin mengatasi masalahnya sendiri, menolak bantuan orang tua dan guru-guru (Hurlock, 1980). Kemampuan remaja untuk memecahkan masalahnya secara adekuat berpengaruh terhadap bagaimana ia mudah mencari pemecahan masalah. Hal ini juga berkaitan dengan mudahnya ia menyalahkan lingkungan dan lebih melihat faktor-faktor di luar dirinya yang menentukan segala sesuatu (Klasik, 2008). Masa remaja adalah masa dimana remaja merasa tertantang jiwa mandirinya untuk mengatasi masalah kompleks yang tengah dihadapinya. Pada masa ini remaja ingin membuktikan kemampuan mereka dalam menyelesaikan masalah sesuai dengan karakteristik pribadi mereka, baik dengan cara berusaha mencari penyebab setiap masalah, melampiaskan pada objek/benda, maupun bernegosiasi dengan orang yang dipercaya.

Berdasarkan hasil penelitian erhadap variabel mekanisme koping 'causioness' dengan kenakalan remaja maka diperoleh $\rho$ value 0,0819 . Hal ini menunjukkan bahwa tidak ada hubungan yang berrmakna antara mekanisme koping 'causioness' dengan kenakalan pada remaja. Berdasarkan hasil penelitian tersebut diketahui bahwa terdapat 11 orang $(13,8 \%)$ dari kenakalan ringan, 5 orang $(6,3 \%)$ dari kenakalan sedang, dan 18 orang $(22,5 \%)$ dari kenakalan berat yang menggunakan mekanisme koping 'causioness'. Hal ini menunjukkan bahwa mekanisme koping 'causioness' dapat digunakan oleh remaja dengan kenakalan ringan, sedang, maupun berat.

Setiap remaja selalu berusaha mencari penyebab masalah dan mengatasi sendiri setiap masalahnya menurut cara yang mereka yakini, meskipun pada akhirnya banyak remaja yang menemukan bahwa penyelesaiannya tidak selalu sesuai 
dengan harapan mereka (Hurlock, 1980).

Para remaja merasa diri mandiri, sehingga mereka ingin mengatasi masalahnya sendiri, menolak bantuan orang tua dan guru-guru (Hurlock, 1980). Pada dasarnya setiap remaja mempunyai kemampuan untuk menyadari serta mencari penyebab masalahnya, namun sejauhmana kemampuan remaja dalam memecahkan setiap permasalahan sangat tergantung kepada karakteristik individu tersebut.

Sedangkan hasil dari penelitian mengenai variabel mekanisme koping 'instrumental action' dengan kenakalan remaja maka diperoleh nilai $\rho$ value 0,002 . Hal ini menunjukkan bahwa ada hubungan yang berrmakna antara mekanisme koping 'instrumental action' dengan kenakalan pada remaja. Berdasarkan hasil penelitian tersebut diketahui bahwa terdapat 13 orang $(16,3 \%)$ remaja dengan kenakalan berat menggunakan mekanisme koping 'instrumental action'. Sedangkan remaja dengan kenakalan ringan dan sedang tidak ada yang menggunakan mekanisme koping 'instrumental action'. Hal ini menunjukkan bahwa mekanisme koping 'instrumental action' hanya digunakan oleh remaja dengan kenakalan berat. Pada remaja dengan kenakalan berat (misalnya pengguna NAPZA) biasanya memiliki konsep diri yang negatif dan harga diri yang rendah. Mereka memiliki perkembangan emosi yang terhambat, dengan ditandai oleh ketidakmampuan mengekspresikan emosinya secara wajar, mudah cemas, pasif, agresif dan cenderung depresi (Klasik, 2008)..

Hasil penelelitian selanjutnya mengenai variabel mekanisme koping 'negotiation' dengan kenakalan remaja maka diperoleh nilai $\rho$ value 0,005 . Hal ini menunjukkan bahwa ada hubungan yang berrmakna antara mekanisme koping 'negotiation' dengan kenakalan pada remaja. Berdasarkan hasil penelitian tersebut diketahui bahwa terdapat 11 orang $(13,8 \%)$ remaja dengan kenakalan ringan menggunakan mekanisme koping 
'negotiation'. Sedangkan remaja dengan kenakalan sedang dan berat juga menggunakan mekanisme koping 'negotiation', namun dengan persentase yang lebih kecil. Hal ini menunjukkan bahwa mekanisme koping 'negotiation' cenderung digunakan oleh remaja dengan kenakalan ringan. Setiap remaja perlu mendapatkan masukan dari orang lain selain teman sebaya jika menghadapi masalah di rumah atau lingkungan sosial. Kebanyakan remaja dengan penyimpangan perilaku, seperti pengguna NAPZA dan remaja yang suka berjudi lebih suka berdiam diri dengan masalah mereka. Akibatnya, kadangkala langkah yang diambil menjadi masalah. Berbincang dengan konselor atau guru dapat membantu jika keluarga tidak memahami masalah remaja (Syahmi, 2007).

\section{SIMPULAN DAN SARAN \\ SIMPULAN}

Dari hasil penelitian dapat ditarik simpulan bahwa terdapat hubungan yang bermakna antara penggunaan mekanisme koping yang berfokus pada masalah dengan kenakalan pada remaja. Setiap remaja yang melakukan kenakalan menggunakan mekanisme koping yang berbeda-beda.

\section{SARAN}

Siswa diharapkan dapat menggunakan mekanisme koping yang adaptif (causioness dan negotiation) sehingga dapat menyelesaikan setiap permasalahan dengan baik serta tidak menggunakan mekanisme koping mal adaptif (instrumental action) dalam menyelesaukan masalah. Bagi siswa yang menggunakan mekanisme koping mal adaptif disarankan untuk mengontrol emosi dengan mengikuti terapi-terapi yang telah diterapkan pengurus panti (seperti static group) guna membicarakan dan memecahkan permasalahan secara bersama-sama. Materi pelatihan serta penerapan terapi untuk mengontrol emosi dan pemecahan masalah (static group, encounter group) hendaknya lebih sering 
diberikan guna kematanngan emosi dan membantu cara pemecahan masalah. Pemberian materi serta pelatihan psikologis remaja perlu lebih banyak diberikan kepada mahasiswa, mengingat jumlah remaja yang rawan terhadap perilaku menyimpang yang kian meningkat. Penelitian yang selanjutnya diharapkan dapat menggunakan variabel mekanisme koping yang lainnya serta dapat menggunakan desain penelitian yang lain agar hasil penelitian tidak hanya berlaku untuk satu waktu. Peneliti selanjutnya juga diharapkan dapat menilai sejauhmana penggunaan mekanisme koping tersebut dalam beberapa tahap perkembangan remaja.

\section{DAFTAR PUSTAKA}

1. Al-Mighwar, M. 2006. Psikologi Remaja, Petunjuk bagi Guru dan Orangtua. Pustaka Setia: Bandung.

2. Arianto. 2008. Psikologi Remaja. Retrieved from http.smileboys.com/2008/07/psikologi -remaja.htm on 12 Maret 2019.
3. Arikunto, S. 2006. Prosedur Penelitian Suatu Pendekatan Praktik. Rineka Cipta: Jakarta.

4. BKKBN. 2006. Pergaulan Remaja Makin Mengkhawatirkan. Retrieved from http://www. prov.bkkbn. go.id.kenakalan\%20remaja/BKKBN\% 20-\%20Rubrik.htm on 12 Maret 2019

5. Davison, C., Gerald, dkk. Editor: Fajar, N. 2006. Psikologi Abnormal Edisi ke-9. Rajagrafindo Persada: Jakarta.

6. Elizabeth B., Hurlock. Editor: Max, R. S. Drs. 1980. Psikologi Perkembangan, Suatu Pendekatan Sepanjang Rentang Kehidupan, edisi kelima. Gelora Aksara Pratama: Jakarta.

7. Hidayat, A. 2003. Riset Keperawatan dan Teknik Penulisan Ilmiah. Salemba Medika: Jakarta.

8. Hidayat, A. 2007. Metode Penelitian Keperawatan dan Teknik Analisis Data. Salemba Medika: Jakarta.

9. Kartini,K. Dr., 2003. Patologi Sosial 2 Kenakalan Remaja. Rajagrafindo Persada: Jakarta.

10. Klasik. 2008. Makalah Jiwa 2 (NAPZA). Retrieved

11. from http://kla5ik.blogspot.com/2008/06/ma kalah-jiwa-2-NAPZA-tinjauan.html on 18 Maret 2019 
12. Monks F.J., dkk, 2004. Psikologi Perkembangan Pangantar Dalam Berbagai Bagianny. Gadjah Mada University Press: Yogyakarta.

13. Mustikasari. 2006. Mekanisme koping. Mustika Sari's Weblog.com.

14. Notoadmodjo, S. Dr. 2005. Metodologi Penelitian Kesehatan. Rineka Cipta: Jakarta.

15. Nursalam. 2003. Konsep dan Penerapan Metodologi Penelitian Ilmu Keperawatan: Pedoman Skripsi, Tesis, dan Instrumen Penelitian Keperawatan. Edisi Pertama. Salemba Medika: Jakarta.

16. Potter, Perry. 2005. Editor: Yulianti, D. Ester, M. Buku Ajar Fundamental Keperawatan Konsep, proses, dan praktik Edisi 4. EGC: Jakarta.

17. Profil Panti Sosial Marsudi Putra Dharmapala Indralaya. 2008. Pengurus PSMPD Indralaya.

18. Sarwono, SW. 2005. Psikologi Remaja. Rajagrafindo Persada: Jakarta.

19. Stuart, G. Sundeen, S. 1998. Buku Saku Keperawatan Jiwa, edisi 3. EGC: Jakarta.

20. Sugiono. 2005. Statistik Untuk Penelitian. Cetakan ke-3. CV. Alfabeta: Bandung.

21. Syahmi, Faris. 2007. Masalah Remaja Lagi?. $\quad$ Retrieved from http://farissyahmi.wordpress.com/auth or/farissyahmi/ on 12 Juni 2009.

22. Tisna. 2003. Perilaku Bermasalah Remaja Muncul Lebih Dini. Retrieved from http.index.com/2003/10/Perilaku Remaja.shtml on 12 Maret 2009.

23. Wahyuningsih, Sri. 2004. Peran Keharmonisan Keluarga dan Konsep diri pada Kenakalan Remaja. Retreved from http://www.damandiri.or.id/file/ ulfahmariaugmbab1.pdf on 12 Juni 2009

24. Wahyuningsih, Sri. 2008. Pengaruh Keluarga terhadap Kenakalan Remaja. Retrieved from http: //www. Feeds feedsburner. com/ r/BungaKehidupan/ 6/1, on 3 April 2009.

25. Wangmuba. 2009. Kenakalan Remaja dan Faktor yang Mempengaruhinya. Retrieved from http://www.wangmuba.com/2009/03/0 4/kenakalan-remaja-dan fakor-yangmempengaruhinya on 12 Maret 2009. 